\section{EREM 73/2}

Journal of Environmental Research, Engineering and Management Vol. 73 / No. 2 / 2017 pp. $21-40$
Performance Evaluation and Sensitivity Analysis of ASTER and SRTM

$(30 \mathrm{~m})$ DEM-derived Terrain Variables in Landslide Susceptibility Assessment: A Case from the Western Ghats

\title{
Performance Evaluation and Sensitivity Analysis of ASTER and SRTM (30m) DEM-derived Terrain Variables in Landslide Susceptibility Assessment: A Case from the Western Ghats
}

\section{M.V. Ninu Krishnan}

State Emergency Operation Centre (SEOC), Kerala State Disaster Management Authority Institute of Land and Disaster Management, P.T.P Nagar, Thiruvanathapuram, Kerala, India - 695038

\section{M.A. Sharath Mohan}

Inter University Centre for Geoinformation Science and Technology, University of Kerala

Kariavattom, Thiruvananthapuram, Kerala, India - 695581

\section{P. Pratheesh}

Department of Geology, School of Earth Science Systems, Central University of Kerala Vidyanagar campus, Kasaragod, Kerala, India - 671123

\section{Hamza Vijith}

Department of Applied Geology, Faculty of Engineering and Science, Curtin University

Sarawak Campus CDT 250, 98009 Miri, Sarawak, Malaysia

\section{Corresponding author: vijithh@gmail.com}

HamzaVijith, Department of Applied Geology, Faculty of Engineering and Science, Curtin University, Sarawak Campus CDT 250, 98009 Miri, Sarawak, Malaysia 
Performance and sensitivity of freely available equal resolution space-borne digital elevation model derivatives in landslide susceptibility analysis were carried out in a selected part of the Western Ghats, India. ASTER and SRTM digital elevation models having a 30-m resolution were used to derive the terrain variables such as slope, aspect, relative relief, slope length and steepness, curvature, landform and stream networks. Most of the variables showed spatial variability in distribution pattern, which affects the results of geo-environmental processes analysed. Sensitivity and performance of each variable derived from the digital elevation models were assessed by preparing landslide susceptibility index (LSI) maps using the Information Value (InfoVal) technique and were validated through receiver operator characteristics (ROC) curve analysis. LSI maps generated point towards the capability of the SRTM digital elevation model to correctly generate the terrain variables than the ASTER elevation surface, by giving the accuracy of LSI maps greater than those produced using the ASTER-derived parameters ( 0.77 and 0.72 for SRTM; 0.67 and 0.65 for ASTER). The results of the present study suggest that the SRTM digital elevation data are more sensitive and suitable for terrain analysis and earth surface process modelling than the ASTER elevation data sets, although both possess equal resolutions.

Keywords: ASTER, SRTM, sensitivity, landslide susceptibility, ROC, Western Ghats.

\section{Introduction}

The research related to the earth surface process heavily depends on digital elevation models (DEM) from various sources and resolutions. Conventionally, the elevation information was often extracted from topographical sheets, in which the elevation is depicted as contour lines. Most topographical sheets are found to be old and not updated. Moreover, the accuracy of the derived elevation surfaces depends on the capacity and expertise of the analyst, who converts the contour lines into the digital format using geographical information systems, which seems to be time consuming and contains non-rectifiable errors. This has been overcome by the increased availability of moderate to high resolution and real near time digital elevation models available from space-borne sources. The most commonly used, moderate resolution digital elevation models are from the shuttle radar topography mission (SRTM) with a 90-m resolution and advanced space-borne thermal emission and reflection radiometer (ASTER) with a $30-\mathrm{m}$ resolution. $\mathrm{A}$ large number of studies have been carried out using both digital elevation models in different aspects of the earth and environmental sciences, which is not only limited to hydrological modelling but also in disaster management, terrain analysis and surface process modelling (Kamp, 2005, Huggel et al., 2008, Hengal et al., 2010, 2011, Cook et al., 2012, Frey and Paul, 2012, Śleszyński 2012, Wang et al., 2012, Pan et al.,
2013, Jing et al., 2014, Akbari et al., 2015, Ouerghi et al., 2015). Besides this, numerous researchers have compared both the DEMs and their performance in different terrain conditions by resampling the SRTM or ASTER data into a base resolution (Hilton et al., 2003, Kervyn et al., 2008, Hirt et al., 2010, Heras et al., 2012, Mukherjee et al., 2013, Rawat et al., 2013, Jozsa et al., 2014, Dewitt et al., 2015). The comparison has facilitated the complementary use of SRTM and ASTER data to overcome the limitations of both data sets. At the end of the year 2014, NASA released the enhanced SRTM data with a 30-m resolution for the whole globe, which facilitated the geoscientist to make much better representations of surface phenomena with increased accuracy (NASA, 2014, USGS, 2015). In the latest version of SRTM data, most of the voids are filled with the available ASTER elevation datasets. This has made the SRTM 30-m data a unique, high resolution, errorless digital elevation model, which is ready to use in any application.

Although a number of studies have reported about the sensitivity and performance of digital elevation model derivatives in hydrological and terrain analysis, all are based on the previously available moderate resolution $(90 \mathrm{~m})$ SRTM and ASTER $(30 \mathrm{~m})$ data. Resampling techniques used to make the resolution uniform will smoothen the elevation values based on the technique used (bilinear, cubic or bi-cubic) with a defined 
window size. This will reduce the sensitivity of the elevation surfaces to correctly deriving the variables and give an averaged parameter outputs (Wolock and Price, 1994, Dixon and Earls, 2009, Zhang et al., 1999, Claessens et al., 2005, Sørensen and Seibert, 2007, Wu et al., 2008, Tan et al., 2015, Zhang et al., 2015). The present study was framed with the objective to analyse the sensitivity and determine the best suitable digital elevation data (30-m ASTER or SRTM) derived terrain parameters in landslide susceptibility zonation (LSZ) mapping in highly undulating terrain in the Western Ghats.

\section{Materials and method}

\section{Study area}

The upper catchment region of the River Manimala, which covers an area of $99 \mathrm{~km}^{2}$, between north latitudes $9^{\circ} 30^{\prime}$ to $9^{\circ} 40^{\prime}$ and east longitudes $76^{\circ} 50^{\prime}$ to $77^{\circ}$ $00^{\prime}$, considered to be the transition zone between the Grater Periyar Plateau on the eastern side and a steep sloping margin on the western side (Fig. 1). The highest elevation in the area is $>1300 \mathrm{~m}$ above the sea level (covers portion of the Grater Periyar Plateau) and the lowest is $<80 \mathrm{~m}$ of valley flats in the foothill regions. Geologically, the area forms a part of the South Indian Granulite terrain and most of the area covered by charnockites, followed by quartzite and dolorites. Soil formation in the area is very low, which is controlled by the lithology and the slope of the terrain. Soil depth is found to be varied from a few centimetres to less than $2 \mathrm{~m}$, with predominating lateritic soils. Geomorphologically, the area is classified into $5 \mathrm{ma}$ jor features such as plateau, escarpments, denudational-structural hills, denudational slope and valley fill with a varying degree of elevation and slope. The area shows a mosaic land use pattern with various land cover types, such as plantations (tea, rubber and teak), mixed agricultural lands (pine apple, pepper, etc.), open mixed forests, grasslands and open scrublands. The area is reported to be witnessing rainfall-induced repeated landslides and soil slips in the highly sloping terrains, where intense agricultural activity is present. The study area receives 2 monsoon rainfall seasons (SW and NE monsoons) with the annual average rainfall more than $3,500 \mathrm{~mm}$.

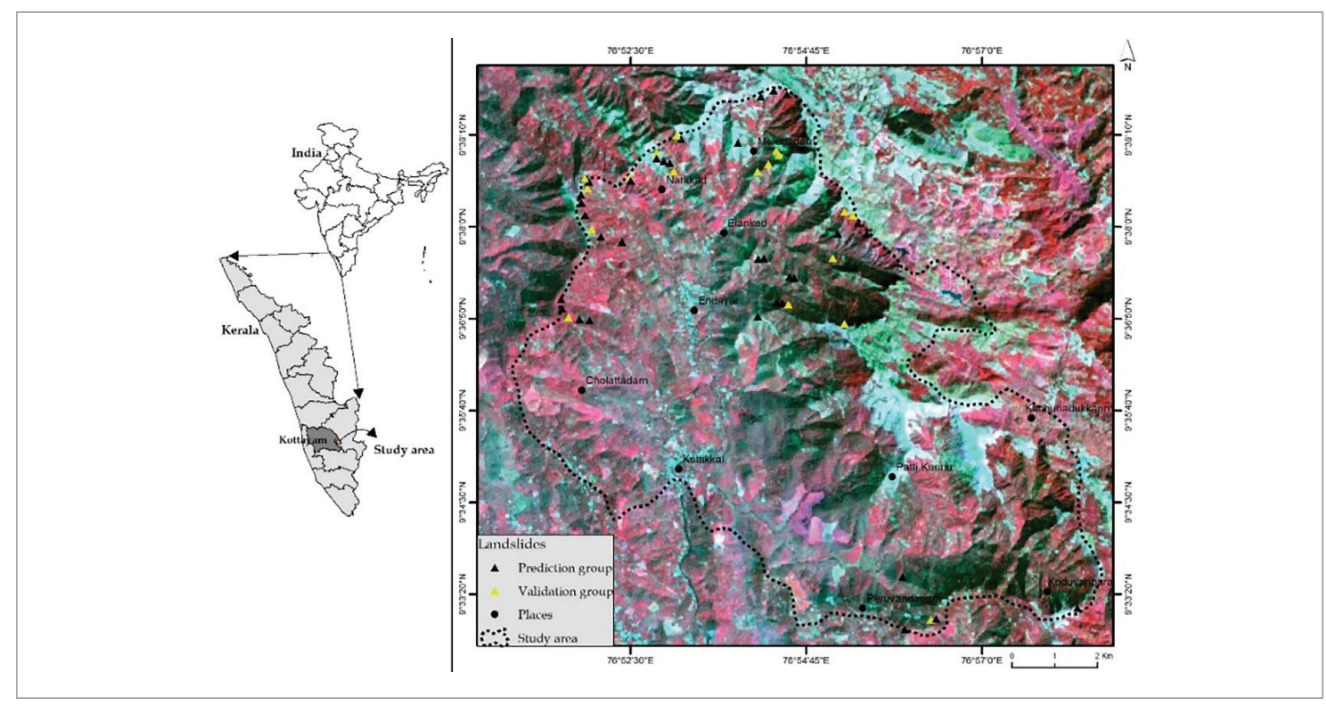

Fig. 1

Study area location map

\section{Methodology}

Preparation of a landslide susceptibility zonation (LSZ) map is considered as the basic and most important step in mitigating the landslide related hazards and framing new development plans for the areas considered to be susceptible to landslides (Brenning, 2005, Kanungo et al., 2009, Kouli et al., 2009, Yalcin et al., 2011, Althuwaynee et al., 2012, Pourghasemi et 
al., 2013, Demir et al., 2015). In LSZ mapping, terrain variables that are considered to be making the terrain susceptible to landslide are derived from digital elevation models. The present study makes a firsthand assessment of sensitivity and suitability of equal resolution digital elevation (30 $\mathrm{m}$ ASTER and SRTM) derived terrain parameters in landslide susceptibility assessment. The sensitivity of digital elevation models in deriving terrain variables was also determined through parameter characterization. Then, the landslide susceptibility zonation maps were prepared using the terrain parameters that are derived from both the DEMs to determine the best suitability and its influence over the landslide susceptibility mapping.

Landslide susceptibility mapping was carried out on the scale of 1:50,000, using terrain variables (slope, aspect, relative relief, slope length and steepness, curvature, landforms), stream networks (drainage density) derived from digital elevation models and the normalised difference vegetation index (NDVI) based land use / land cover and fracture density was derived from a Landsat image. The majority of the variables used in the analysis were derived from the digital elevation models in order to analyse the sensitivity of LSZ maps. Information and database regarding the palaeoslide locations are considered as the most crucial information needed to generate the LSZ map of any area (Ayalew et al., 2004, Yilmaz, 2009, Pourghasemi et al., 2014, Regmi et al., 2014, Eker et al., 2015). In the present analysis, 52 landslide initiation locations were mapped from the field. Random selection criteria were used to divide the whole data into 2 groups to avoid the biases of the analyst in selecting the landslides to be used for the generation of weights of each thematic maps and validation of final LSZ map. Among them, 34 landslides were used for weight determination and 18 landslides were kept to validate the LSZ maps using the receiver operating characteristic (ROC) curve analysis technique. A bivariate statistical analysis technique known as information value (InfoVal) was used for the landslide susceptibility assessment (van Westen, 1997, Jade and Sarkar, 1993, Yin and Yan, 1988, Wu et al., 2000, Zezere, 2002, Vijith et al., 2009, Balasubramani and Kumaraswamy, 2013). The InfoVal method of landslide susceptibility analysis works on the basis of cross comparison of landslide density and terrain parameter density, which is straightforward, unbiased and purely a data-driven technique. This also allows the analyst to incorporate the field expertise in parameter generation and its segmentation, which support the selection of proper instability factors to be involved in the landslide susceptibility analysis. InfoVal works on individual classes in the variable analysed like other bivariate statistical techniques and returns a value which determines the role of a particular class in making the terrain susceptible to the landslide. The feature class weights can be calculated using the equation:

$$
\mathrm{W}_{\mathrm{i}}=\log \text { (Densclass / Desnsmap) }
$$

where

$\mathrm{W}_{\mathrm{i}}$ is the weight for the $\mathrm{i}^{\text {th }}$ class of a particular thematic map; Densclass is the failure density in the factor class; and Densmap is the failure density within the whole study area.

The equation (1) can be rewritten as:

$$
\begin{aligned}
& \mathrm{W}_{\mathrm{i}}=\log \left[\left(\mathrm{N}_{\text {pix }}\left(\mathrm{S}_{\mathrm{i}}\right) / \mathrm{N}_{\text {pix }}\left(\mathrm{N}_{\mathrm{i}}\right)\right) /\right. \\
& \left.\left(\sum_{i=1}^{n} \mathrm{~N}_{\text {pix }}\left(\mathrm{S}_{\mathrm{i}}\right) / \sum_{i=1}^{n} \mathrm{~N}_{\text {pix }}\left(\mathrm{N}_{\mathrm{i}}\right)\right)\right]
\end{aligned}
$$

where

$N_{\text {pix }}\left(S_{i}\right)$ is the number of failed pixels in the $i^{\text {th }}$ factor class; $N_{\text {pix }}\left(N_{i}\right)$ is the number of pixels in the $i^{\text {th }}$ factor class; and $\mathrm{n}$ is the number of classes in the thematic map.

Two sets of digital elevation models used to generate the terrain variables were downloaded from the data repository managed by the Japan Space Agency and USGS. ASTER elevation data (ASTER GDEM version 2) were downloaded from the website http:// gdem.ersdac.jspacesystems.or.jp/ and the SRTM data (1 arc second) from http://earthexplorer.usgs. gov (Figure 2). The information about the data acquisition systems and other details can be found in Farr and Kobrick (2000), Werner (2001), GLCF (2004), 
Rodriguez et al., (2005), Far et al., (2007), Tachikawa et al. (2011), and USGS (2015). The downloaded elevation data sets were clipped with an extended study area map and used for further processing. Before generating terrain attributes from the DEMs, the voids were filled with DEM reconditioning and fill DEM modules available in the ArcHydro tools using ArcGIS. This has given hydrologically corrected DEMs. These elevation surfaces were used for further processing.

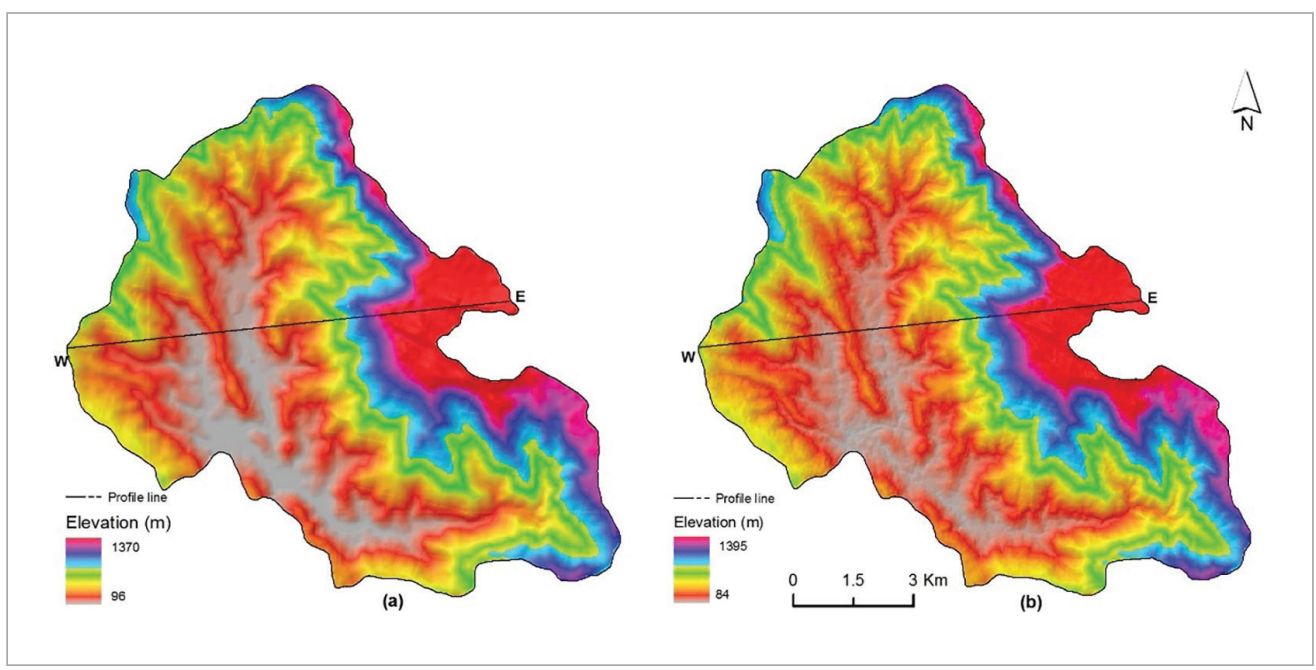

Fig. 2

ASTER and SRTM elevation surfaces showing cross profile location

\section{Results and Discussion}

\section{Suitability analysis}

The suitability of each elevation dataset in the study area was analysed by comparing the elevation points extracted from the Sol toposheets, ASTER and SRTM through the linear regression analysis. This gave a correlation of $0.98\left(R^{2}=0.971\right.$ and 0.976 for ASTER and SRTM, respectively) for both the datasets with toposheet derived elevation (Figure 3). The root mean square error (RMSE) is calculated for both the data sets varying from \pm 62 (SRTM) to $\pm 76 \mathrm{~m}$ (ASTER) while compared with toposheet elevation whereas the RMSE is very low $( \pm 26 \mathrm{~m})$ with a high correlation coefficient (0.99) between SRTM and ASTER. This confirms the selection of ASTER and SRTM elevation datasets for the present study. A cross profile depicting the elevation variation from both the DEMs was plotted from West to East by including maximum variation (Figure 4). The profiles indicate variation in height and characteristics of the topography. In this, the SRTM is found to be smoother and devoid of sharp changes in elevation values and can be considered as representing the real near surface condition. The characteristics of the study area can be well explained from the elevation profiles.

\section{Fig. 3}

Linear plot showing the cross correlation between toposheetderived elevation points with ASTER and SRTM elevation points

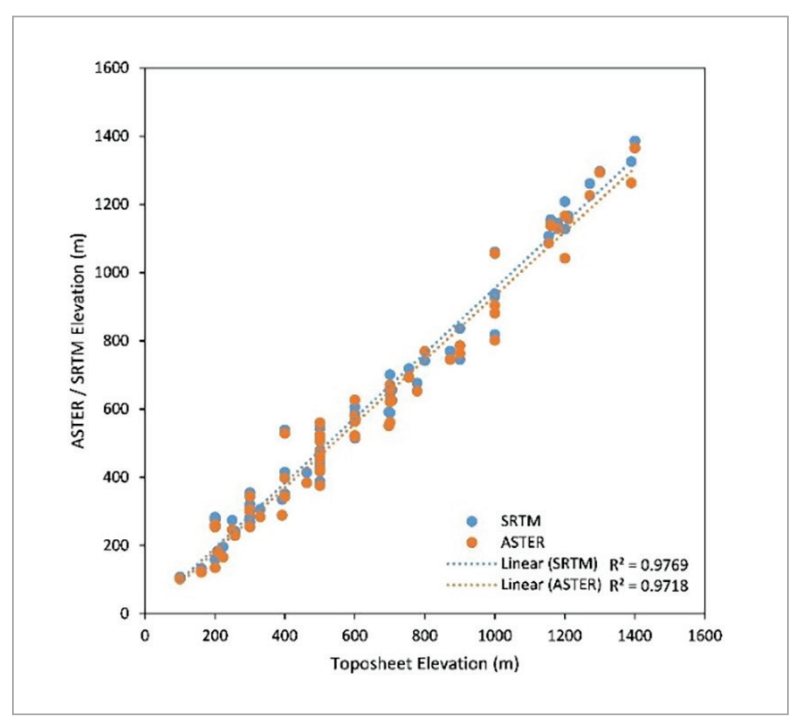


The eastern side of the study area shows maximum elevation, gently undulating and short sloping surfa$\mathrm{ce}$, which is the characteristic feature of the plateau region. Some of the segments indicate the concordant summits. Following the gently undulating terrain, a long, steep sloping surface, which represents the side slope (westward) of the plateau, appears and occupies nearly $20 \%$ of the surface profiles. The long, steep sloping surface ends in terrain with characteristic undulations and finally to the broad river valley. From the river valley, further westward show highly undulating terrain characteristics with continuous hills, slopes and in between valleys.

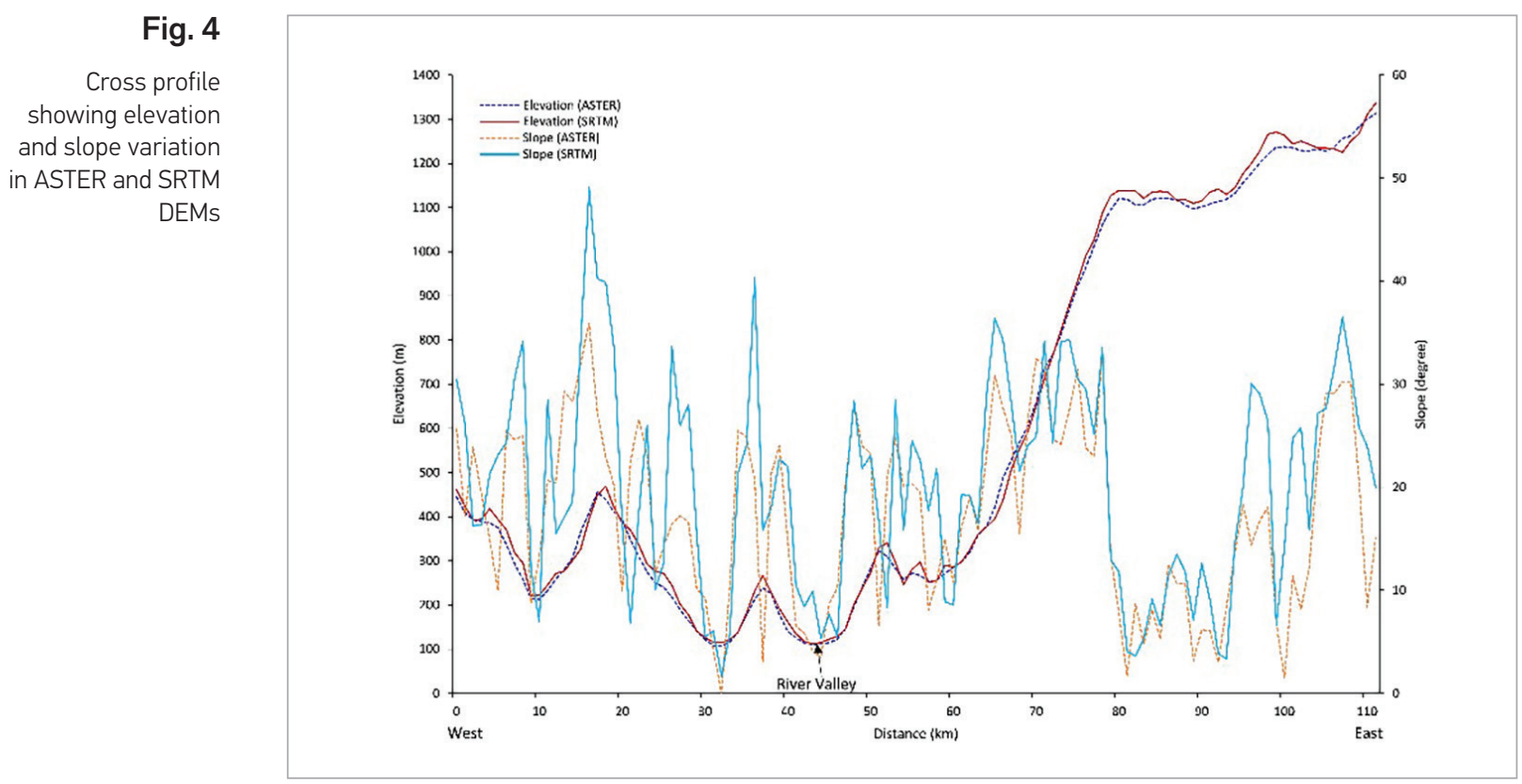

\section{DEM derivatives variation analysis}

Six topographic variables such as slope, aspect, relative relief, slope length and steepness, curvature and landform were generated from both the elevation data sets in order to assess the variability of derivatives in its value and spatial distribution. The basic characteristics of the elevation distribution and other topographic variables derived are presented in Table 1. The lowest elevation for both data was $96 \mathrm{~m}$ and $84 \mathrm{~m}$, whereas the maximum elevations were 1,370 and $1,395 \mathrm{~m}$ for ASTER and for SRTM DEMs, respectively. Area distribution of elevation datasets was performed by classifying both the DEMs into 13 different classes of elevation. This classification does not show much variation in the area corresponding to each class of elevation except the lowest elevation class $<100 \mathrm{~m}$, in which the SRTM occupies less area compared with the ASTER elevation surface.
The slope surface derived showed maximum values $65^{\circ}$ and $64^{\circ}$ for ASTER and SRTM, respectively (Figure 5 a $\&$ b). The classification of slope surfaces into 6 classes showed a slight variation in spatial distribution in both the data (Figure 6 a). Similarly, the slope profiles indicated a high variation in the slope derived from ASTER and SRTM elevation surfaces (Figure 4). Among them, the lowest slope was plotted by the ASTER surface in the gently undulating, high elevation region (6 $6^{\circ}$ variation with an SRTM-derived slope), whereas the highest slope was marked by SRTM derived slope surface in the moderate elevation region (> $16^{\circ}$ variation with an ASTER-derived slope). This will have an impact on analysis results of the environmental processes, which use the digital elevation surface for deriving the slope parameter. The slope aspect, which determines the direction of the slope, was generated and reclassified to understand the 
spatial variation in the distribution (Figure $5 \mathrm{c} \& d$ ). It was found that the aspect surfaces shows equal distribution in all classes except in the flat region. The ASTER-derived aspect showed more flat areas than that of SRTM (Figure $6 \mathrm{~b}$ ). Changes in the elevation in the unit area, which influences the geomorphic process operating in the area, are termed as a relative relief. The range neighbourhood function based generation of a relative relief map from both the DEMs gave the outputs with a maximum variation in the lowest and highest values (Figure 5 e \& f)). The ASTER-derived relative relief surface showed a range of values between 21-766 m/ $\mathrm{km}^{2}$, whereas the SRTM based range showed between $52-810 \mathrm{~m} / \mathrm{km}^{2}$. The reclassification of relative relief maps showed the variation in the distribution of each range, particularly in the classes of $100-200 \mathrm{~m} / \mathrm{km}^{2}, 400-500 \mathrm{~m} / \mathrm{km}^{2}$ and $>500 \mathrm{~m} / \mathrm{km}^{2}$ (Figure $6 \mathrm{c}$ ). In the class range $100-200 \mathrm{~m} / \mathrm{km}^{2}$, the ASTER-derived relative relief map occupies more area than that of SRTM. However, it was also noted that with the higher relative relief ranges $\left(400-500 \mathrm{~m} / \mathrm{km}^{2}\right.$ and $\left.>500 \mathrm{~m} / \mathrm{km}^{2}\right)$ the SRTM-derived surface occupies more area than the ASTER-derived relative relief map. This indicates the capability of SRTM, which almost correctly detected the surface elevation.

Table 1

Basic statistical characteristics of terrain variable generated from ASTER and SRTM DEMs

\begin{tabular}{|c|c|c|c|c|c|}
\hline & Min. & Max. & Mean & STD & \\
\hline 1 & 2 & 3 & 4 & 5 & 6 \\
\hline Elevation (m) & 96 & 1370 & 477.38 & 316.7 & \multirow{5}{*}{ ASTER } \\
\hline Slope (degree) & 0 & 65 & 19.41 & 10.15 & \\
\hline Relative Relief (m/km²) & 21 & 766 & 331.64 & 145.72 & \\
\hline Slope length and steepness & 0 & 37 & 6.89 & 4.43 & \\
\hline Curvature & -9 & 9 & -0.003 & 0.59 & \\
\hline \multirow{5}{*}{ SRTM } & 84 & 1395 & 486.31 & 317.55 & Elevation (m) \\
\hline & 0 & 64 & 21.68 & 10.73 & Slope (degree) \\
\hline & 52 & 810 & 352.79 & 147.63 & $\begin{array}{l}\text { Relative Relief } \\
\left(\mathrm{m} / \mathrm{km}^{2}\right)\end{array}$ \\
\hline & 0 & 46 & 7.57 & 4.73 & $\begin{array}{l}\text { Slope length and } \\
\text { steepness }\end{array}$ \\
\hline & -15 & 18 & -0.003 & 1.15 & Curvature \\
\hline
\end{tabular}

The most crucial erosion controlling parameter, which cumulates the effects of length of slope and its steepness, was also derived from both the digital elevation models. The LS factor generated from both the elevation surfaces showed variability in the spatial distribution and also in the highest values, i.e., 37 and 46 for ASTER- and SRTM-derived surfaces, respectively (Figure $5 \mathrm{~g} \& \mathrm{~h}$ ). The discretisation of LS values showed maximum differences in the lowest class $(0-5)$ and a minimum variation in the class ranges $10-15$ and 15-20 (Figure $6 \mathrm{~d}$ ). The classification also allows the assessment of spatial domain distributions, and it was noted that the distribution of class 3 (15-20) was more crucial in the area and was going to play a major role in the erosivity-related issues. Many researchers have used plan and profile curvatures independently to identify the erosional and depositional surface in the area under study (Drăgut and 
Blaschke, 2006, Klingseisen et al., 2008, Nefeslioglu et al., 2010, Evans, 2012). Plan curvature measures the rate of change of slope perpendicular to the slope direction, whereas the profile curvature measures the rate of change of slope parallel to the down slope direction. In order to assess the cumulative effect of the curvature in the terrain characterisation by classifying the terrain into a positive (convex), negative (concave) and flat surfaces, the total curvature was generated from both the elevation surfaces (Figure $5 \mathrm{i} \& \mathrm{j}$ ). Curvature generated from the ASTER DEM ranges from -9 to 9 , whereas that of
SRTM-derived surface vary between -15 to 18 . The grouping of curvature values into concave, flat and convex curvatures yielded a maximum difference in the flat surface category. The ASTER-derived curvature surface showed a larger area as flat than those of SRTM (Figure 6 e). The reverse scenario was observed in the case of convex surface area, where SRTM showed more area than ASTER. The major changes in the area and spatial distribution will have a high influence on the results of the analysis of geo-environmental phenomenon like landslide and soil erosion assessments.

Fig. 5

Parameters derived from ASTER and SRTM DEMs: (a \& b) slope; (c \& d) aspect; (e \& f) relative relief

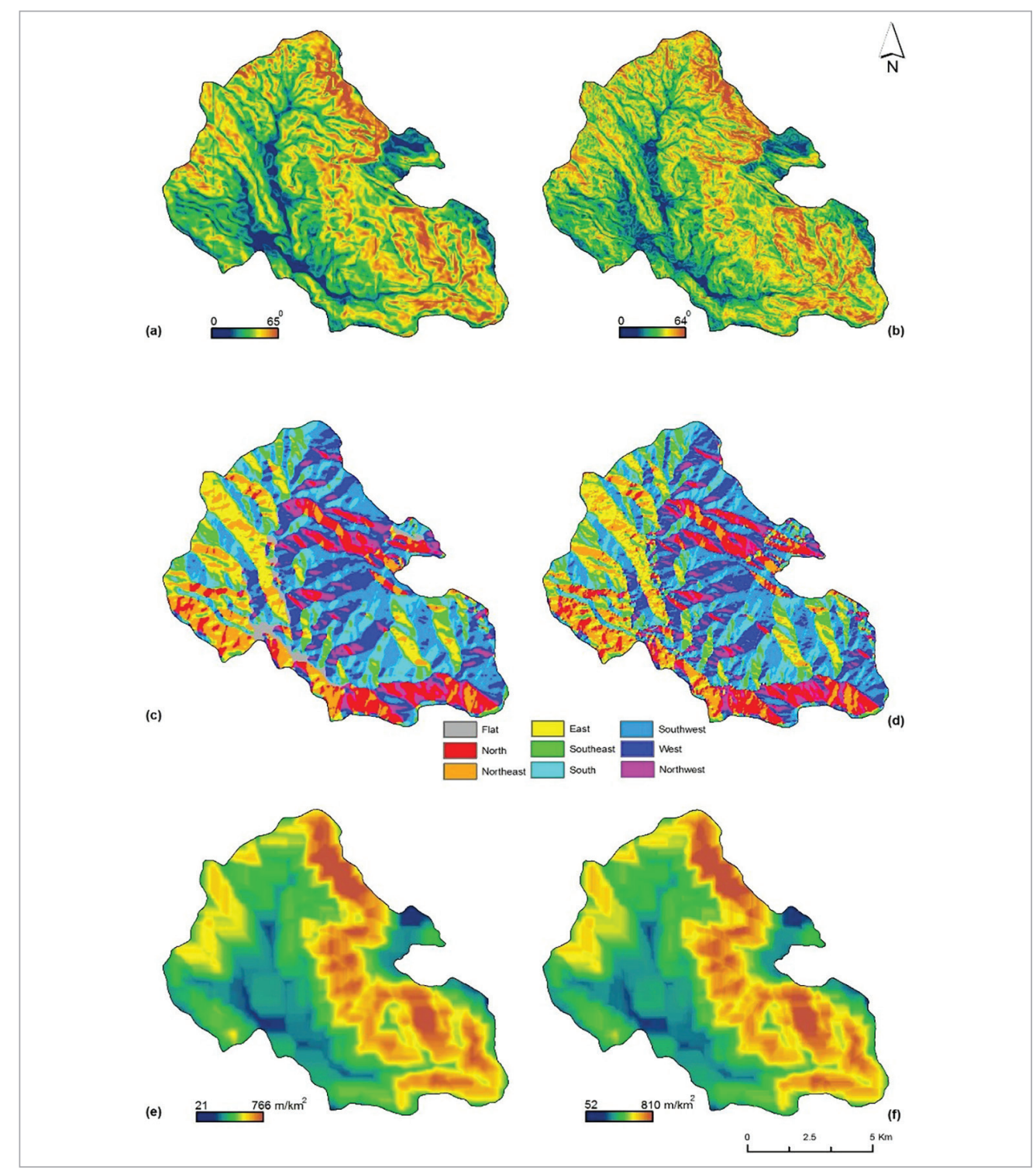




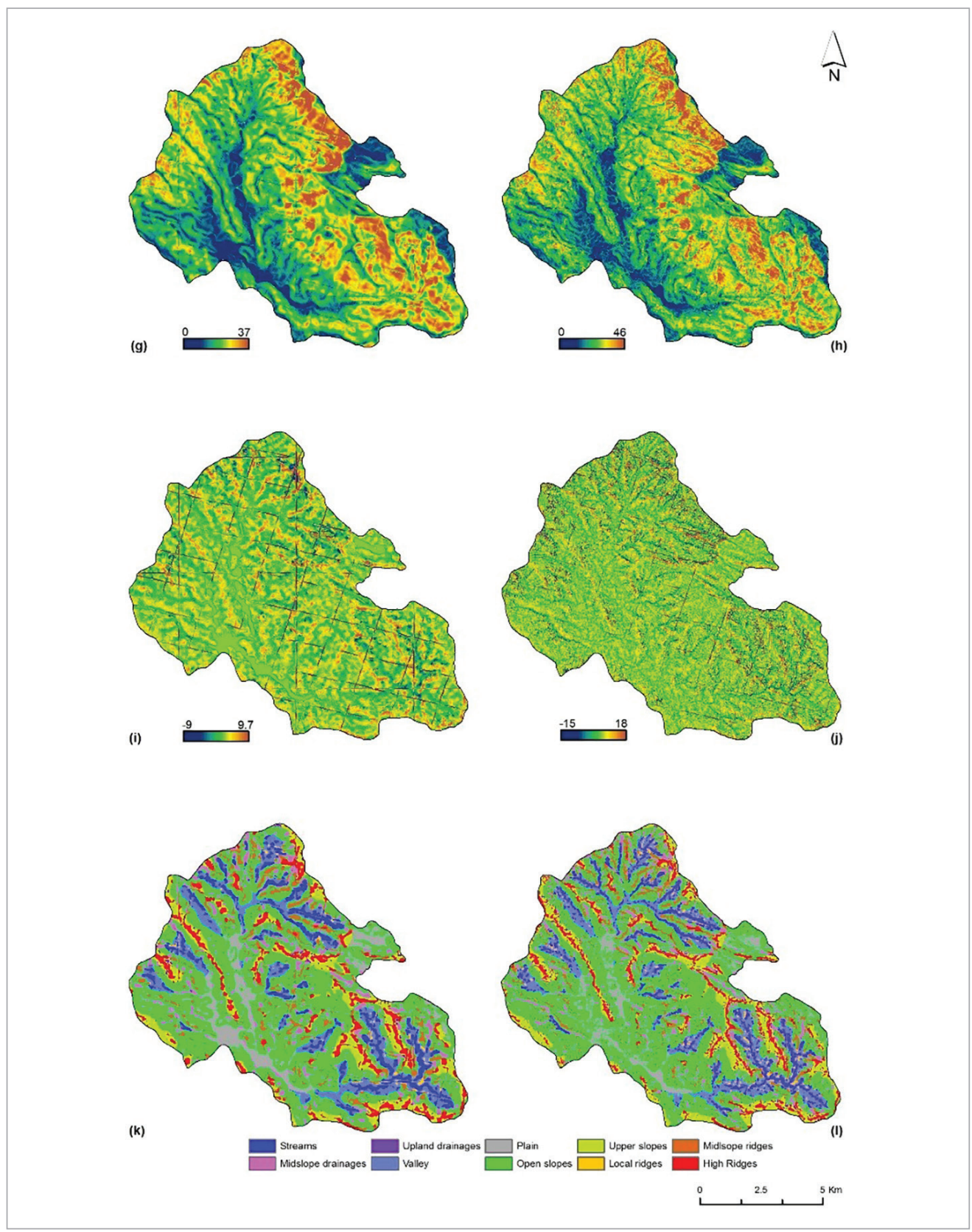

\section{Fig. 5}

Parameters derived from ASTER and SRTM DEMs: $(g \& h)$ LS; (i \& j) curvature; $(\mathrm{k} \& \mathrm{l})$ landform
An attempt was also made to classify the study area into different landforms based on the model proposed by Guisan et al. (1999), using the topographic position index (Weiss, 2000), which works on the concept of a mean neighbourhood of elevation values and its categorisation. The landform classes can be compared with the geomorphology of the terrain, which also divides the terrain into different features. Digital elevation model based landform analysis resulted in 10 categories, such as high ridges, mid-slope ridges, local ridges, upper slopes, open slopes, plain, valley, upland drainages, midland drainages and streams (Figure $5 \mathrm{k} \& \mathrm{l}$ ). The area distribution of each class of landform was within the same ranges for both elevation sources, unlike the other parameters (Figure 6 f), and a slight variation was noticed in the landform 
class under plain. This indicates the capability of both elevation surfaces in generating the landform classes in almost equal manner and can be used for the regions similar to the study area. The performance of digital elevation models in deriving the hydrological parameters from highly undulating terrains was also characterised by generating the stream networks. Channel networks derived through the same criteria were tagged with Strahler's stream order and the length of each segment was calculated (Figure $5 \mathrm{~m} \&$ n). Basic statistics of stream networks derived from both digital elevation surfaces are given in Table 2. It was found that both elevation surfaces behaved very differently in the generation of the basic hydrological parameter. ASTER-derived stream networks showed maximum numbers of segments as 1,605, whereas those of SRTM were 2,924. While considering the stream order based segments, a wide variation in the number of segments is noticed in the first and second order streams. Moreover, stream networks derived from SRTM elevation surface showed close resemblance to the real terrain conditions, which in turn confirms the suitability of SRTM elevation data in the generation of hydrological parameters and processes.

Fig. 5

Parameters derived from ASTER and SRTM DEMs: $m \& n$ - stream networks

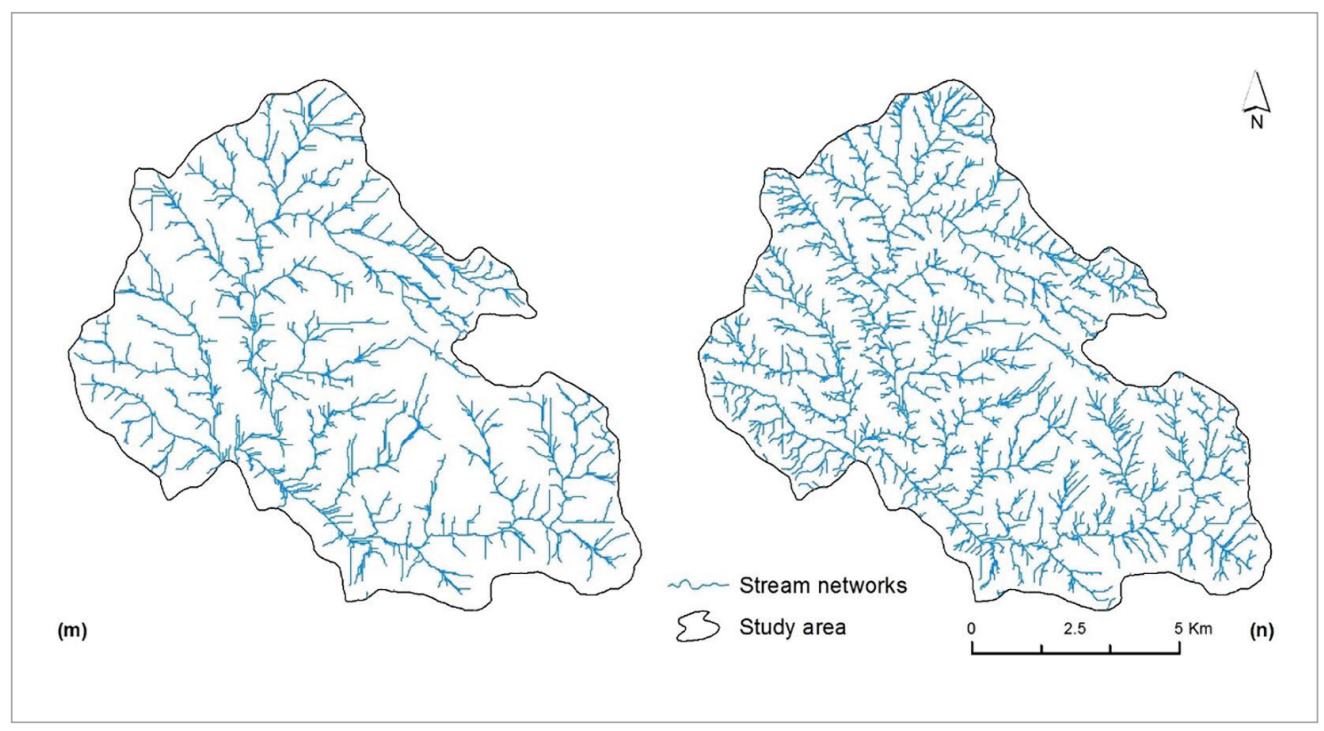

Table 2

Comparison of drainage networks delineated from ASTER and SRTM DEMS

\begin{tabular}{c|c|c|c|c}
\hline \multirow{2}{*}{ Stream Order } & \multicolumn{2}{|c|}{ Number of segments } & \multicolumn{2}{c}{ Length $(\mathrm{km})$} \\
\cline { 2 - 5 } & ASTER & SRTM & ASTER & 5 \\
\hline 1 & 2 & 3 & 4 & 258.01 \\
\hline 2 & 826 & 1,507 & 68.748 & 108.19 \\
\hline 3 & 337 & 657 & 44.102 & 50.17 \\
\hline 4 & 227 & 317 & 20.65 & 37.24 \\
\hline 5 & 102 & 258 & 18.66 & 17.01 \\
\hline 6 & 110 & 121 & 0.39 & 8.99 \\
\hline
\end{tabular}


Fig. 6

Graphical representation of area distribution in ASTER- and SRTM-derived terrain variables: a) slope, b) aspect, c) relative relief, d) LS, e) curvature, f) landform

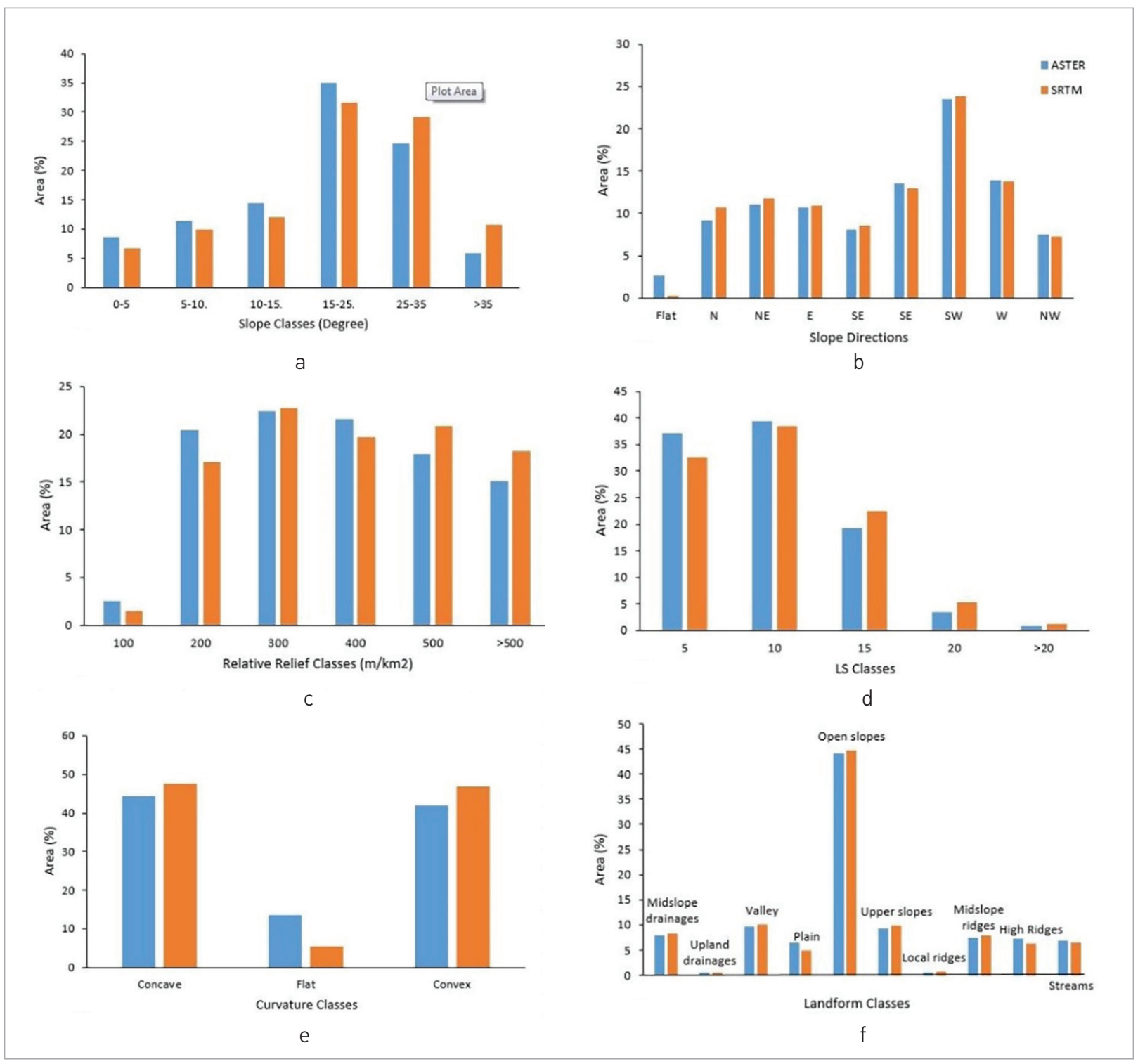

\section{Performance comparison of variables through landslide susceptibility analysis}

The suitability and the sensitivity of digital elevation model based terrain variables in landslide susceptibility mapping were determined by the production of landslide susceptibility index (LSI) maps. The individual weights or contribution of features classes of each thematic variable used in the analysis were derived using the InfoVal technique, by comparing the distribution of already mapped landslides with data layers. The InfoVal weights calculated for each thematic feature classes are given in Table 3. The close examination of the derived InfoVal weights of each parameter from digital elevation models showed a slight variation in the distribution of landslide occurrence and area of particular feature classes. While comparing the InfoVal weights of ASTER- and SRTM-derived slope 


\section{Table 3}

InfoVal weights derived for the parameters considered in the LSI generation

\begin{tabular}{c|c|c|c|c|c|c|c}
\hline \multirow{2}{*}{ Parameter / Class } & \multicolumn{2}{|c|}{ Landslide (Pixel) } & \multicolumn{2}{c|}{ Area (pixel) } & \multicolumn{2}{c}{ InfoVal weight (In) } \\
\cline { 2 - 8 } & ASTER & SRTM & ASTER & SRTM & ASTER & SRTM \\
\hline Slope & 2 & 1 & 9,603 & 7,299 & -0.39 & -0.81 \\
\hline $0-5$ & 3 & 4 & 12,644 & 10,968 & -1.59 & -0.72 \\
\hline $5-10$ & 1 & 2 & 15,937 & 13,301 & -0.68 & -0.77 \\
\hline $10-15$ & 6 & 5 & 38,632 & 34,986 & 32,203 & 0.65 & 0.48 \\
\hline $15-25$ & 16 & 16 & 27,222 & 6,553 & 11,834 & 1.09 & 0.50 \\
\hline $25-35$ & 6 & 6 & & &
\end{tabular}

\section{Aspect}

\begin{tabular}{c|c|c|c|c|c|c}
\hline Flat & 0 & 0 & 2,917 & 277 & -5 & $-5 \#$ \\
\hline$N$ & 5 & 5 & 10,126 & 11,876 & 0.47 & 0.31 \\
\hline NE & 4 & 5 & 12,174 & 12,977 & 0.07 & 0.23 \\
\hline E & 9 & 8 & 11,887 & 12,019 & 0.90 & 0.77 \\
\hline SE & 4 & 4 & 8,893 & 9,457 & 0.38 & 0.32 \\
\hline SE & 6 & 4 & 15,005 & 14,350 & 0.26 & -0.10 \\
\hline SW & 3 & 6 & 25,959 & 26,427 & -0.98 & -0.30 \\
\hline W & 2 & 1 & 15,382 & 15,225 & -0.86 & -1.54 \\
\hline NW & 1 & 1 & 8,248 & 7,983 & -0.93 & -0.90 \\
\hline
\end{tabular}

Relative Relief

\begin{tabular}{c|c|c|c|c|c|c}
\hline$<100$ & 0 & 0 & 2,809 & 1,624 & -5 & $-5 \#$ \\
\hline $100-200$ & 1 & 1 & 22,587 & 18,854 & -1.94 & -1.76 \\
\hline $200-300$ & 5 & 3 & 24,829 & 25,106 & -0.42 & -0.95 \\
\hline $300-400$ & 15 & 12 & 23,854 & 21,840 & 0.72 & 0.58 \\
\hline $400-500$ & 10 & 13 & 19,856 & 23,034 & 0.49 & 0.61 \\
\hline$>500$ & 3 & 5 & 16,656 & 20,133 & -0.53 & -0.21 \\
\hline
\end{tabular}

Slope length and Steepness

\begin{tabular}{c|c|c|c|c|c|c}
\hline 5 & 9 & 7 & 41,186 & 36,096 & -0.34 & -0.46 \\
\hline 10 & 10 & 14 & 43,456 & 42,460 & -0.29 & 0.07 \\
\hline 15 & 14 & 11 & 21,261 & 24,943 & 0.76 & 0.36 \\
\hline 20 & 1 & 2 & 3,892 & 5,796 & -0.18 & 0.12 \\
\hline$>20$ & & & 796 & 1,296 & -5 & $-5 \#$ \\
\hline
\end{tabular}




\begin{tabular}{|c|c|c|c|c|c|c|}
\hline \multirow{2}{*}{ Parameter / Class } & \multicolumn{2}{|c|}{ Landslide (Pixel) } & \multicolumn{2}{|c|}{ Area (pixel) } & \multicolumn{2}{|c|}{ InfoVal weight (ln) } \\
\hline & ASTER & SRTM & ASTER & SRTM & ASTER & SRTM \\
\hline \multicolumn{7}{|l|}{ Curvature } \\
\hline Concave & 16 & 15 & 49,145 & 52,760 & 0.06 & -0.08 \\
\hline Flat & 2 & 3 & 14,957 & 5,956 & -0.83 & 0.49 \\
\hline Convex & 16 & 16 & 46,489 & 51,875 & 0.11 & 0.0032 \\
\hline \multicolumn{7}{|l|}{ Landform } \\
\hline Mid-slope drainages & 2 & 2 & 8,810 & 9,186 & -0.30 & -0.35 \\
\hline Upland drainages & 1 & 1 & 407 & 678 & 2.08 & 1.57 \\
\hline Valley & 0 & 0 & 10,795 & 11,065 & -5 & $-5 \#$ \\
\hline Plain & 0 & 0 & 5,940 & 5,345 & -5 & $-5 \#$ \\
\hline Open slopes & 10 & 14 & 49,439 & 49,489 & -0.42 & -0.08 \\
\hline Upper slopes & 11 & 13 & 10,410 & 10,989 & 1.23 & 1.35 \\
\hline Local ridges & 0 & 0 & 588 & 876 & -5 & $-5 \#$ \\
\hline Mid-slope ridges & 2 & 1 & 8,503 & 8,823 & -0.27 & -1.00 \\
\hline High Ridges & 8 & 3 & 8,085 & 7,100 & 1.17 & 0.32 \\
\hline Streams & 0 & 0 & 7,614 & 7,040 & -5 & $-5 \#$ \\
\hline
\end{tabular}

Drainage Density

\begin{tabular}{l|c|c|c|c|c|c}
\hline Low 750 & 10 & 9 & 11,989 & 7,777 & 1.00 & 1.33 \\
\hline Medium 1,500 & 22 & 25 & 72,727 & 74,956 & -0.02 & 0.08 \\
\hline High $>1,500$ & 1 & 0 & 25,875 & 27,858 & -2.07 & $-5 \#$ \\
\hline
\end{tabular}

Fracture density

\begin{tabular}{l|c|c|c}
\hline Low $\left(250 \mathrm{~m} / \mathrm{km}^{2}\right)$ & 17 & 27,699 & 0.69 \\
\hline Medium $(<750$ & 10 & 54,681 & -0.52 \\
\hline High $>750$ & 7 & 28,211 & -0.21 \\
\hline LULC (NDVI) & 1 & 3,864 & -0.17 \\
\hline \begin{tabular}{l|l|l} 
Barren/exposed areas \\
Open scrubs
\end{tabular} & 8 & 21,568 & 0.19 \\
\hline $\begin{array}{l}\text { Vegetation with low } \\
\text { density }\end{array}$ & 18 & 55,519 & 0.05 \\
\hline $\begin{array}{l}\text { Moderately dense } \\
\text { vegetation }\end{array}$ & 5 & 23,034 & -0.35 \\
\hline \begin{tabular}{l} 
Thick vegetation \\
\hline
\end{tabular} & 2 & 6,606 & -0.02 \\
\hline
\end{tabular}


classes, it was noted that high susceptibility with a greater number of landslide occurrences for the slope classes greater than $25^{\circ}$, but the InfoVal weight value is highly variable. This is due to the changes in the area dimension of particular classes derived from both DEMs. The same pattern was also observed in aspect, relative relief and landform. The other parameters like slope length and steepness (LS), curvature and drainage density showed much variation between the feature class weights. In the theme fracture density, a greater number of landslides were reported from the low density zone, showing a high InfoVal weight while compared with high and medium fracture density zones. In the case of land use / land cover, the low vegetation density class covered more area and many of the landslides were reported from that zone. To generate the LSZ map, the weights derived for the individual sets of thematic map classes were assigned to produce the InfoVal thematic maps, which represent the positive and the negative contribution to the susceptibility of landslides. Then, using the raster calculator option of ArcGIS spatial analyst, these InfoVal thematic maps were integrated to produce the landslide susceptibility index (LSI) map. This gave 2 LSI maps, one with ASTER-derived variables and another with SRTM.

The landslide susceptibility index map produced by using the ASTER-derived variables showed a susceptibility index value varying from -19.50 to 7.49 , whereas that produced by SRTM-derived variables showed susceptibility index ranges from -22.22 to 6.24 (Figure 7 a \& b). Both LSI maps showed spatial variations in the distribution of high susceptibility and its area. The distribution of susceptibility of indexes for both LSI maps was compared, and the variability in the distribution of susceptibility was found to be marginal. In order to reconfirm the sensitivity of LSI maps thus produced to the parameters derived from the digital elevation models, a method of omission was introduced to reproduce the LSI maps. In this, the variables (fracture density and land use / land cover) that were not generated from digital elevation models were removed from the calculation of the LSI map. Then, the

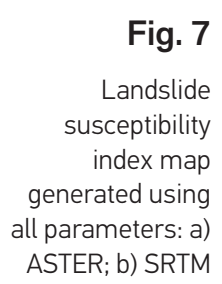

Fig. 7 usceptibility generated using ASTER; b) SRTM

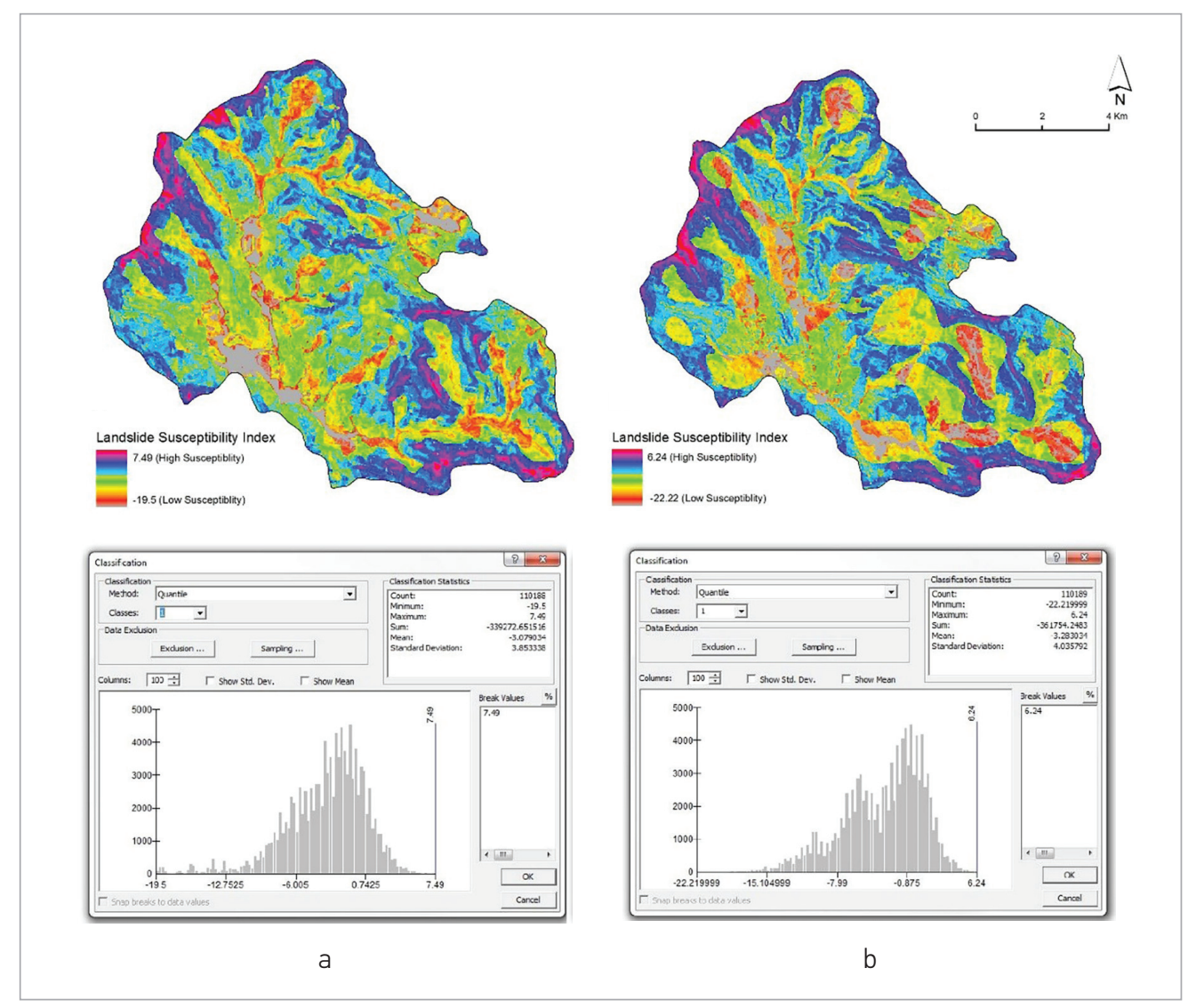


raster calculator was used to integrate all other InfoVal weighted themes to produce the LSI maps. The LSI map thus produced showed susceptibility index ranges from -16.56 to 5.61 for ASTER and -16.35 to 4.08 for SRTM themes (Figure $8 \mathrm{a} \& \mathrm{~b}$ ). The analysis of the distribution of susceptibility values of each LSI maps showed a high variability in its distribution compared with those generated with all parameters. Table 4 shows the general statistical parameters of the generated LSI maps. These indicate the normalising effect of other parameters over the DEM-derived variable in the landslide susceptibility mapping and the sensitivity of equal resolution, different sourced digital elevation models in landslide susceptibility mapping.

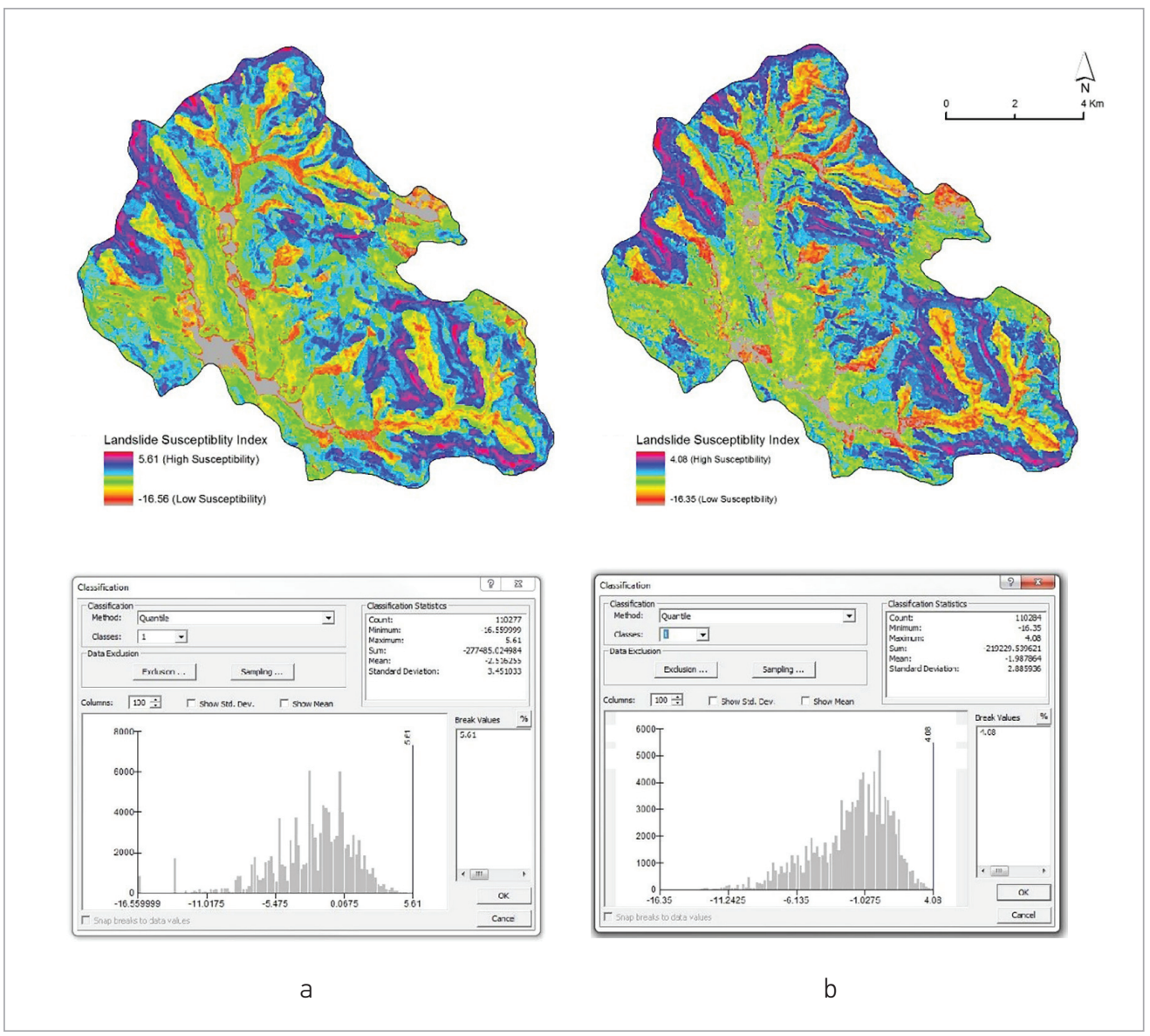

Fig. 8

Landslide susceptibility index map generated using DEM-derived variables only: a) ASTER; b) SRTM

Table 4

Comparison of statistical parameters of LSI maps

\begin{tabular}{|c|c|c|c|c|c|c|c|c|}
\hline \multirow[b]{2}{*}{ Source elevation } & \multicolumn{4}{|c|}{ LSI (all parameters) } & \multicolumn{4}{|c|}{ LSI (DEM derivatives only) } \\
\hline & Minimum & Maximum & Mean & $\begin{array}{l}\text { Standard } \\
\text { deviation }\end{array}$ & Minimum & Maximum & Mean & $\begin{array}{l}\text { Standard } \\
\text { deviation }\end{array}$ \\
\hline 1 & 2 & 3 & 4 & 5 & 6 & 7 & 8 & 9 \\
\hline SRTM & -22.21 & 6.24 & -3.22 & 4.03 & -16.35 & 4.07 & -1.98 & 2.88 \\
\hline ASTER & -19.5 & 7.48 & -3.02 & 3.85 & -16.59 & 5.61 & -2.47 & 3.45 \\
\hline
\end{tabular}




\section{Sensitivity and specificity of LSI maps - the ROC statistics}

The landslide susceptibility analysis resulted in 4 LSI maps, of which 2 represent LSI maps with all parameters and another 2 maps are based on DEM-derived parameters only. The suitability, reliability and accuracy of the produced LSI maps were determined by validating with 18 numbers of landslides, through the receiver operating characteristic (ROC) curve analysis. The ROC curve works on the basis of occurrence and non-occurrence of events, which can be considered as the probability of true or false prediction based on different cut-offs (Williams et al., 1999, Alonzo and Pepe, 2002, Fawcett, 2006). The area under the ROC curve is used as the measure of predictive accuracy of the model and ultimately reflects the sensitivity of the parameters used to produce the LSI maps. If the area under the curve (AUC) reaches 1, it indicates a perfect prediction and those below 1 indicate variation in accuracy in different magnitudes (Yesilnacar and Topal, 2005, Beguería, 2006, Mancini et al., 2010, Nandi and Shakoor, 2010). Two groups of LSI maps were validated by assessing the AUC and both showed a variation in AUC among LSI generated by the same sets of parameters (Table 5). LSI maps prepared using the terrain variable generated from ASTER data shown lower AUC (0.67 and 0.65) than those generated from SRTM data (0.77 and 0. 72). LSI maps generated by using the variables derived from the SRTM digital elevation model come in the class of fair predictability, whereas that of ASTER-derived falls in the class of poor predictability. This indicates the sensitivity of SRTM elevation data sets and its usability in predictive modelling of terrain process.

\section{Table 5}

Results of the sensitivity analysis performed using ROC curve techniques

\begin{tabular}{|c|c|c|c|c|c|}
\hline \multicolumn{6}{|c|}{ Area under the curve ( all parameters) } \\
\hline \multirow{2}{*}{$\begin{array}{l}\text { Test result } \\
\text { variable(s) }\end{array}$} & \multirow{2}{*}{$\begin{array}{c}\text { Area under the } \\
\text { curve }\end{array}$} & \multirow{2}{*}{ Std. error ${ }^{a}$} & \multirow{2}{*}{ Asymptotic sig. ${ }^{b}$} & \multicolumn{2}{|c|}{ Asymptotic $95 \%$ confidence interval } \\
\hline & & & & Lower bound & Upper bound \\
\hline 1 & 2 & 3 & 4 & 5 & 6 \\
\hline LSI_SRTM & .769 & .078 & .006 & .615 & .922 \\
\hline LSI_ASTER & .673 & .090 & .076 & .496 & .850 \\
\hline \multicolumn{6}{|c|}{ Area under the curve ( DEM variables only) } \\
\hline LSI_SRTM & .718 & .086 & .026 & .549 & .886 \\
\hline LSI_ASTER & .651 & .092 & .121 & .471 & .832 \\
\hline
\end{tabular}

\section{Conclusions}

The present study focuses on the determination of performance of equal resolution digital elevation models in deriving the terrain variables and its sensitivity in landslide susceptibility zonation mapping. ASTER and SRTM elevation datasets with a spatial resolution of $30 \mathrm{~m}$ were used in the comparative assessment. The statistical assessment of elevation data compatibility with the toposheet elevation showed a close correlation (0.98) of both elevation datasets, which confirms the suitability of both data sets in the present analysis. The performance of each elevation data set in deriving the terrain parameters facilitated the determination of performance of the data sources and a total of seven topographic and hydrological parameters was derived from both elevation datasets. Derived variables did not show much variation in the values, but the spatial pattern was highly variable. Among the variables, the major 
difference was noted in slope, relative relief, LS and curvature along with the stream networks derived. The influence of this variability, in cumulative analysis was tested by preparing the landslide susceptibility index maps using the same variables through the InfoVal technique. The resulted LSI maps reflected the sensitivity of terrain variables (different source) used in the analysis and were characterised by the ROC curve techniques. The ROC curve analysis revealed the capacity of SRTM elevation datasets to correctly derive the terrain parameters by providing the LSI map with the prediction accuracy of 0.77 , assessed through the area under curve analysis, which is considered as above the acceptable limit, whereas that of ASTER-derived LSI map showed poor predictability with an area under the curve of 0.67 . In order to reconfirm the sensitivity of the terrain parameters derived from the digital elevation models, an omission technique based assessment of LSI was

\section{References}

Akbari A., Ramli N.I.B., Kong N.S. (2015). Application of public domain satellite-based DEMs in natural hazard modeling. International Journal of J Environmental Sciences and Developmet 72.

Alonzo T.A., Pepe M.S. (2002). Distribution $\square$ free ROC analysis using binary regression techniques. Biostatistics 33: 421-432.

Althuwaynee O.F., Pradhan B., Lee, S. (2012). Application of an evidential belief function model in landslide susceptibility mapping. Computers and Geosciences 44:120-135.

Ayalew L., Yamagishi H., Ugawa N. (2004). Landslide susceptibility mapping using GIS-based weighted linear combination, the case in Tsugawa area of Agano River, Niigata Prefecture, Japan. Landslides 11:73-81.

Balsubramani K., Kumaraswamy K. (2013). Application of geospatial technology and information value technique in landslide hazard zonation mapping: a case study of Giri Valley, Himachal Pradesh. Disaster Advances 6:38-47.

Beguería S. (2006). Validation and Evaluation of Predictive Models in Hazard Assessment and Risk Management. Natural Hazards 37(3):315-329.

Brenning A. (2005). Spatial prediction models for landslide hazards: review, comparison and evaluation. Natural Hazards and Earth System Sciences 5:853-862. carried out by delimiting the effect of other parameters, such as fracture, drainage density and land use / land cover. This also shows a similar result with the acceptability and sensitivity of SRTM based terrain parameters in producing more accurate LSI maps than the ASTER-derived terrain variables, by providing the AUC 0.72 and 0.65 for SRTM and ASTER based LSI maps, respectively.

Although the results of comparison of elevation values of both DEMs with toposheet data points gave the high correlation, the data distribution was found to vary widely. This has resulted in the differentiation and variable sensitivity of terrain variables from both the elevation surfaces. From the results of the suitability assessment and sensitivity analysis performed, it can be concluded that, although both DEMS possess equal resolution, the SRTM DEM represents the near real surface condition, is more sensitive with less error and confirms its suitability in similar studies.

Claessens L., Heuvelink G.B.M., Schoorl J.M., Veldkamp A. (2005). DEM resolution effects on shallow landslide hazard and soil redistribution modelling. Earth Surface Processes and Landforms 304: 461-477.

Cook A.J., Murray T., Luckman A., Vaughan D.G., Barrand N.E. (2012). A new 100-m Digital Elevation Model of the Antarctic Peninsula derived from ASTER Global DEM: methods and accuracy assessment. Earth System Science Data 4:129-142

Demir G., Aytekin M., Akgun A., (2015). Landslide susceptibility mapping by frequency ratio and logistic regression methods: an example from Niksar-Resadiye Tokat, Turkey. Arabian Journal of Geosciences 83:1801-1812.

DeWitt J.D., Warner T.A., Conley J.F. (2015). Comparison of DEMS derived from USGS DLG, SRTM, a statewide photogrammetry program, ASTER GDEM and LiDAR: implications for change detection. GIScience and Remote Sensing 522:179-197.

Drăguț L., Blaschke T. (2006). Automated classification of landform elements using object-based image analysis. Geomorphology 813:330-344.

Eker A.M., Dikmen M., Cambazoğlu S., Düzgün Ş.H., Akgün H. (2015). Evaluation and comparison of landslide susceptibility mapping methods: a case study for the Ulus district, Bartın, northern Turkey. International Journal of Geographical Information Science 291: 132-158. 
Evans I.S. (2012). Geomorphometry and landform mapping: What is a landform?. Geomorphology 1371:94-106.

Farr T.G., Kobrick M. (2000). Shuttle Radar Topography Mission produces a wealth of data. American Geophysics Union EOS. 81:583- 585.

Farr T.G., Rosen P.A., Caro E., Crippen R., Duren R., Hensley S., Kobrick, M., Paller, M., Rodriguez, E., Roth, L., (2007). The shuttle radar topography mission. Reviews of Geophy. 45:RG2004. doi:10.1029/2005RG000183.

Fawcett, T., 2006. An introduction to ROC analysis. Pattern recognition letters. 278,861-874.

Frey H., Paul F. (2012). On the suitability of the SRTM DEM and ASTER GDEM for the compilation of topographic parameters in glacier inventories. International Journal of Applied Earth Observation and Geoformation 18:480-490.

GLCF. (2004). ASTER Technical Guide. Accessed from http:// glcf.umd.edu/library/guide/techguide_aster.pdf (accessed on 10.01.2015).

Hengl T., Heuvelink G.B.M., Van Loon E.E. (2010) On the uncertainty of stream networks derived from elevation data: The error propagation approach. Hydrology and Earth System Sciences 7:767-799.

Heras M.M., Saco P.M., Willgoose G.R. (2012). A Comparison of SRTM V4 and ASTER GDEM for Hydrological Applications in Low Relief Terrain. Photogrammetric Engineering and Remote Sensing 787:757-766.

Hilton R.W., Featherstone P., Berry C., Kirby J. (2003). Comparison of digital elevation models over Australia and external validation using ERS-1 satellite radar altimetry. Australian Journal of Earth Science 50:157-168.

Hirt C., Filmer M.S., Featherstone W.E. (2010). Comparison and validation of the recent freely available ASTER-GDEM ver1, SRTM ver4. 1 and GEODATA DEM-9S ver3 digital elevation models over Australia. Australian Journal of Earth Science 573:337-347.

Huggel C., Schneider D., Miranda P.J., Granados H.D., Kääb A. (2008). Evaluation of ASTER and SRTM DEM data for lahar modeling: a case study on lahars from Popocatépetl Volcano, Mexico. Journal of Volcanology and Geothermal Research 1701:99-110.

Jade S., Sarkar S. (1993). Statistical model for slope instability classifications. Engineering Geology 36:71-98.

Jing C., Shortridge A., Lin S., Wu J. (2014). Comparison and validation of SRTM and ASTER GDEM for a subtropical landscape in Southeastern China. International Journal of Digital Earth 712: 969-992.
Jozsa E., Fabian S.A., Kovacs M. (2014). An evaluation of EU-DEM in comparison with ASTER GDEM, SRTM and contour-based DEMs over the Eastern Mecsek Mountains. Hungarian Geographical Bullettin 63 (4): 401-423.

Kamp U., Tobias B., Jeffrey O. (2005). Geomorphometry of Cerro Sillajhuay Andes, Chile/Bolivia: comparison of digital elevation models DEMs from ASTER remote sensing data and contour maps. Geocarto International 20 (1):23-33.

Kanungo D.P., Arora M.K., Sarkar S., Gupta R.P. (2009). A fuzzy set based approach for integration of thematic maps for landslide susceptibility zonation. Georisk 31: 30- 43.

Kervyn M., Ernst C.G.J., Goosens R., Jacobs P. (2008). Mapping volcano topography with remote sensing: ASTER vs. SRTM. International Journal of Remote Sensing 29: 6515-6538.

Klingseisen B., Metternicht G., Paulus G. (2008). Geomorphometric landscape analysis using a semi-automated GIS-approach. Environmental Modelling \& Software 231:109-121.

Kouli M., Loupasakis C., Soupios P., Vallianatos F. (2009). Landslide hazard zonation in high risk areas of Rethymno Prefecture, Crete Island, Greece. Natural Hazards 523:599-621.

Mancini F., Ceppi C., Ritrovato G. (2010). GIS and statistical analysis for landslide susceptibility mapping in the Daunia area, Italy. Natural Hazards and Earth System Sciences 109:1851-1864.

Mukherjee S., Joshi P.K., Mukherjee S., Ghosh A., Garg R.D., Mukhopadhyay A. (2013). Evaluation of vertical accuracy of open source Digital Elevation Model DEM. International Journal of Applied Earth Observation and Geoinformation 21: 205-217.

Nandi A., Shakoor A. (2010). A GIS-based landslide susceptibility evaluation using bivariate and multivariate statistical analyses. Engineering Geology 1101: 11-20.

NASA. (2014). NASA Releases Enhanced Shuttle Land Elevation Data. http://www2.jpl.nasa.gov/srtm/. (accessed on 20.7.2015).

Nefeslioglu H.A., Sezer E., Gokceoglu C., Bozkir A.S., Duman T.Y. (2010) Assessment of landslide susceptibility by decision trees in the metropolitan area of Istanbul, Turkey. Mathematical Problems in Engineering. doi:10.1155/2010/901095

Ouerghi S., ELsheikh R.F.A., Achour H., Bouazi S. (2015). Evaluation and Validation of Recent Freely-Available ASTER-GDEM V. 2, SRTM V. 4.1 and the DEM Derived from Topographical Map over SW Grombalia Test Area in North East of Tunisia. Journal of Geographical Information System 703:266.

Pan F., Liao J., Li X., Guo H. (2013). Application of the inundation area-lake level rating curves constructed from the SRTM DEM to retrieving lake levels from satellite measured inundation areas. Computers and Geosciences 52: 168-176. 
Pourghasemi H.R, Jirandeh A. G, Pradhan B., Xu, C., Gokceoglu C. (2013). Landslide susceptibility mapping using support vector machine and GIS at the Golestan Province, Iran. Journal of Earth System Science 1222: 349-369.

Pourghasemi H.R., Pradhan B., Gokceoglu C. (2012). Application of fuzzy logic and analytical hierarchy process AHP to landslide susceptibility mapping at Haraz watershed, Iran. Natural Hazards 632:65-996.

Rawat K.S., Mishra A.K., Sehgal V.K., Ahmed N., Tripathi V.K. (2013). Comparative evaluation of horizontal accuracy of elevations of selected ground control points from ASTER and SRTM DEM with respect to CARTOSAT-1 DEM: a case study of Shahjahanpur district, Uttar Pradesh, India. Geocarto International 285:439-452.

Regmi A.D., Yoshida K., Pourghasemi H.R., Dhital M.R., Pradhan B. (2014). Landslide susceptibility mapping along BhalubangShiwapur area of mid-Western Nepal using frequency ratio and conditional probability models. Journal of Mountain Science 115: 1266-1285.

Rodriguez E., Morris C.S., Blez J.E., Chapin E.C., Martin JM., Daffer W., Hensley S. (2005). An assessment of the SRTM topographic products, Technical Report JPL D-31639, Jet Propulsion Laboratory, Pasadena, California, 143.

Śleszyński P.A. (2012). Geomorphometric analysis of Poland based on the SRTM-3 data. Geographia Polonica 854:45-59.

Sørensen R., Seibert J. (2007). Effects of DEM resolution on the calculation of topographical indices: TWI and its components. Journal of Hydrology 3471: 79-89.

Tachikawa T., Kaku M., Iwasaki A., Gesch D., Oimoen M., Zhang Z., Danielson J., Krieger T., Curtis B., Haase J., Abrams M., Crippen R., Carabaja C. (2011). ASTER Global Digital Elevation Model Version 2 - Summary of Validation Results August 31. accesed from www.jspacesystems.or.jp on 10.01.2015.

Tan M.L., Ficklin D.L., Dixon B., Yusop Z., Chaplot V. (2015). Impacts of DEM resolution, source, and resampling technique on SWAT-simulated streamflow. Applied Geography 63: 357-368.

USGS. (2015). Shuttle Radar Topography Mission SRTM 1 Arc-Second Global. https://tta.cr.usgs.gov/SRTM1Arc. (accessed on 20.7.2015)

van Westen C.J. (1997). Statistical landslide hazard analysis. In: ITC 1997. ILWIS 2.1 for Windows: The Integrated Land and Water Information System. Applications Guide 73-84. Enschede, The Netherlands: ILWIS Department, ITC

Vijith H., Rejith P.G., Madhu G. (2009). Using infoVal method and GIS techniques for the spatial modelling of landslide susceptibility in the upper catchment of River Meenachil in Kerala. Journal Indian Society of Remote Sensing 372:241-250.
Wang W., Yang X., Yao T. (2012). Evaluation of ASTER GDEM and SRTM and their suitability in hydraulic modelling of a glacial lake outburst flood in southeast Tibet. Hydrological Processes 262: 213-225.

Werner M. (2001). Shuttle Radar Topography Mission SRTM, Mission overview. Journal of Telecommunications. Frequenz. 55: 75-79.

Williams C.J., Lee S.S., Fisher R.A., Dickerman L.H. (1999). A Comparison of Statistical Methods for Prenatal Screening for Down Syndrome. Applied Stochastic Models in Business and Industry 15 (2): 89-101.

Wolock D.M., Price C.V. (1994). Effects of digital elevation model map scale and data resolution on a topography-based watershed model. Water Resources Research 30: 3041-3052.

Wu S., Li J., Huang G.H. (2008). A study on DEM-derived primary topographic attributes fir hydrological applications: Sensitivity to elevation data resolution. Applied Geography 28: 210-223.

Wu, Y., Yin, K., Liu, Y. ( 2000). Information analysis system for landslide hazard zonation. E Bromhead, N Dixon and ML Ibsen. Landslides in Research, Theory and Practices. 3: 1593-1598.

Yalcin A., Reis S., Aydinoglu A.C., Yomralioglu T. (2011). A GISbased comparative study of frequency ratio, analytical hierarchy process, bivariate statistics and logistics regression methods for landslide susceptibility mapping in Trabzon, NE Turkey. Catena 853: 274-287.

Yesilnacar, E., Topal, T., 2005. Landslide Susceptibility Mapping: A Comparison of Logistic Regression and Neural Networks Methods in a Medium Scale Study, Hendek Region Turkey. Engi Geol. 79 (3-4), 251-266.

Yilmaz I. (2009). Landslide susceptibility mapping using frequency ratio, logistic regression, artificial neural networks and their comparison: a case study from Kat landslides Tokat-Turkey. Computers and Geosciences 356:1125-1138.

Yin K.L., Yan T.Z. (1988). Statistical prediction model for slope instability of metamorphosed rocks.Landslides-Glissements de Terrain. Proceedings V International Symposium on Landslides. 2:1269-1272.

Zezere J.L., (2002). Landslide susceptibility assessment considering landslide typology. A case study in the area north of Lisbon Portugal. Natural Hazards and Earth System Sciences 2:73-82. doi: http://dx.doi.org/ 10.5194/nhess-2-73-2002.

Zhang X., Drake N.A., Wainwright J., Mulligan M. (1999). Comparison of slope estimates from low resolution DEMs: Scaling issues and a fractal method for their solution. Earth Surface Processes and Landforms 249: 763-779.

Zhang Y., Yan G., Bai Y. (2015). Sensitivity of topographic correction to the DEM spatial scale. Geoscience and Remote Sensing Letters IEEE. 121:53-57. 


\section{ASTER ir SRTM (30 m) DEM-išvestinių vietovès kintamųjų vertinimas ir jautrumo analizè nuošliaužų jautrumo tyrime: Vakarų Ghatų atvejis}

\section{M.V. Ninu Krishnan}

Valstybinis ekstremaliu situaciju centras (SEOC), Kerala valstijos katastrofu valdymo tarnyba Žemès ir katastrofų valdymo institutas, P.T.P Nagar, Thiruvanathapuram, Kerala, Indija

\section{M.A. Sharath Mohan}

Geoinformatikos mokslo ir technologiju centras, Inter universitetas, Kariavattom Thiruvananthapuram, Kerala, Indija

\section{Ponline Pratheesh}

Centrinis Keralos Universitetas, Geologijos katedra,, Žemės sistemų mokslo mokykla Vidyanagar Campus, Kasaragod, Kerala, Indija

\section{HamzaVijith \\ Curtino universitetas, Techninės geologijos katedra, Inžinerijos ir mokslo fakultetas Sarawak Campus CDT 250, 98009 Miri, Sarawak, Malaizija}

Veikla ir jautrumas laisvai prieinamose vienodos raiškos erdvėse sumontuoto skaitmeninio pakèlimo modelio išvestinių nuošliaužu jautrumo savybiu analizeje buvo atlikti pasirinktoje Vakaru Ghatų teritorijoje, Indijoje. ASTER ir SRTM skaitmeniniu pakèlimo modeliai turintys $30 \mathrm{~m}$ rezoliuciją buvo naudojami išvesti vietovès kintamuosius, tokius kaip nuolydis, aspektas, santykinis reljefas, šlaito ilgis ir statumas, kreivumas, žemès formos ir upelių tinklai. Dauguma šių kintamujų rode erdvinius kintamuosius paskirstymo modelyje, kuris turi j̇takos analizuojamiems geo-aplinkos procesams. Kiekvieno šių kintamuju jautrumas, išvestas iš skaitmeninių pakèlimo modelių buvo ivertintas ruošiant nuošliaužu jautrumo indeksu (NJI) žemèlapius, naudojant informacijos vertès (ang.: Information Value (InfoVal)) techniką ir buvo patvirtinti per imtuvo operatoriaus charakteristiku (IOC) kreivès analizę. NJI žemèlapiai sukūre SRTM skaitmeninio pakèlimo modelio taškus, kad būtu galima teisingiau generuoti vietovès kintamuosius, nei ASTER pakèlimo paviršius, pateikdami NJI žemèlapių, kurie yra didesni nei tie, kurie pagaminti naudojant ASTER gautus parametrus ( 0.77 and 0.72 for SRTM; 0.67 and 0.65 for ASTER), tikslumą. Pateikti šio tyrimo rezultatai nurodo, kad SRTM skaitmeniniu pakèlimo duomenys yra jautresni ir labiau tinkami vietovés analizei bei žemès paviršiaus procesų modelevimui nei ASTER pakèlimo duomenu rinkiniai, nors abu turi vienodas rezoliucijas.

Raktiniai žodžiai: ASTER, SRTM, jautrio analizė, nuošliaužų jautrumas, imtuvo operatoriaus charakteristikos, Vakaru Ghatai. 